Canadian Journal of Fisheries and Aquatic Sciences

Canadian

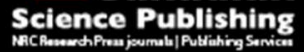

Journal canadien des sciences halieutiques et aquatiques

\title{
Larval fish dispersal along an estuarine-ocean gradient
}

\begin{tabular}{|r|l|}
\hline Journal: & Canadian Journal of Fisheries and Aquatic Sciences \\
\hline Manuscript ID & cjfas-2016-0325.R2 \\
\hline Manuscript Type: & Article \\
\hline Date Submitted by the Author: & 03-Jan-2017 \\
\hline Complete List of Authors: & $\begin{array}{l}\text { Ramos, Sandra; Interdisciplinary Centre of Marine and Environmental } \\
\text { Research (CIIMAR), Rua dos Bragas 289, 4050-123 Porto, Portugal ; } \\
\text { Institute of Estuarine and Coastal Studies, University of Hull } \\
\text { Paris-Limouzy, Claire; University of Miami, } \\
\text { Angélico, Maria Manuel; Instituto Português do Mar e da Atmosfera (IPMA), }\end{array}$ \\
\hline Keyword: & fish larvae; dispersal; estuarine-ocean gradient; nursery function \\
\hline &
\end{tabular}

SCHOLARONE ${ }^{m}$

Manuscripts 
Larval fish dispersal along an estuarine-ocean gradient

Ramos, S. ${ }^{1,2^{*}}$, Paris, $\mathrm{C}^{3}$ and Angélico, M.M ${ }^{4}$

${ }^{1}$ Interdisciplinary Centre of Marine and Environmental Research (CIIMAR), Rua dos Bragas

289, 4050-123 Porto, Portugal ssramos@ciimar.up.pt

${ }^{2}$ Institute of Estuarine and Coastal Studies, University of Hull, Hull HU6 7RX, UK

${ }^{3}$ RSMAS/AMP, University of Miami, 4600 Rickenbacker Causeway, Miami, FL, USA

cparis@rsmas.miami.edu

${ }^{4}$ Instituto Português do Mar e da Atmosfera (IPMA) mmangelico@ipma.pt

* Corresponding author: S. Ramos 


\section{Abstract}

2 The present study investigated the larval fish dispersal along an estuarine-ocean gradient to

3 explore connectivity between ocean and estuaries. During spring 2009, a combined ocean-

4 estuarine survey was conducted along the Lima estuarine salinity gradient and in two transects off

5 the adjacent coast (NW Iberian Peninsula), until the 100m isobaths. Salinity, TPM, POM, TDC, DOC

6 reached higher values at the ocean, chlorophyll $a$ and nutrients increased at the estuary. From the

7 total 56 taxa identified, 14 were present along the gradient, including estuarine species (ES),

8 marine stragglers (MS) and migrants (MM). CCA analysis showed that species were separated

9 along the gradient according to their ecological functional classification. MM associated with high

10 salinity were separated from ES correlated with lower salinities and high chlorophyll $a$

11 concentrations of inner estuary. Flounder showed a typical spatial gradient of MM, with

12 abundance increasing from the ocean towards inner estuary. The dispersal of larvae along the

13 Lima estuarine-ocean gradient was indicative of connectivity between habitats, emphasizing the

14 need to consider this feature in management plans, mainly for species exploited by commercial

15 fisheries.

16

17 Key-words: fish larvae; dispersal; estuarine-ocean gradient; nursery function 


\section{Introduction}

20

21

22

23

24

25

26

27

28

29

30

31

32

33

34

35

36

37

38

39

Dispersal of living organisms implicates departure from the initial site, movement between sites and arrival in a new site (Clobert et al. 2009), and can be defined as the process by which living organisms expand actively or passively the space or range where they live (Cote et al. 2010).

Dispersal is a fundamental life-history trait and a process fundamental to the population dynamics (Schludermann et al. 2012) of spatially structured populations (Cote et al. 2010). The exchange of individuals among geographically separated groups, or connectivity (Cowen et al. 2000) is a major driver of population replenishment (Bignami et al. 2013). Knowledge on connectivity of marine populations is fundamental to establish marine species spatio-temporal dynamics and the links between larval dispersal and supply, juvenile abundance, survival, and contribution to adult stocks (Vasconcelos et al. 2011a), has important applications for management and conservation of ecosystems (Cowen and Sponaugle 2009).

Most marine fish species experience a planktonic larval phase during which they are vulnerable to passive transport by currents or a combination of currents and swimming behavior that ends on dispersing fish larvae through long distances from the initial spawning grounds. During this dispersal phase, many environmental and biological features control larval survivorship, namely the high mortality rates typical of this early development stage (Houde 2008; Miller and Kendal 2009; Johnson et al. 2014; Garrido et al. 2015); or a successful dispersal of fish larvae to suitable nursery areas to ensure the development to the following juvenile phase (Able and Fahay 2010; Sale et al. 2010). After spawning, planktonic fish stages (eggs and larvae) may be advected and passively transported by the water currents (Wolanski 2016 and references therein) and therefore 
40 in order to reach an estuarine nursery area, the fish larvae may need directional swimming and

41 competency to overcome coastal and tidal counter currents. (Wolanski 2016). The pelagic larval

42 phase is dependent on biophysical characteristics related with reproduction strategies, as well as

43 on the interactions between hydrodynamics and behavioral capabilities of individual larvae to

44 reach and settle in favorable habitats (Cowen and Sponaugle 2009; Sale et al. 2010; Amorim et al.

45 2016; Wolanski 2016). Eastern boundary coastal waters are naturally highly dynamic and

46 populated by transient structures such as river plumes, eddies and wind driven currents that

47 contribute to a rather complex environment which could be very challenging for early life stages

48 survival playing a role in dispersal, feeding conditions and exposure to predation (Relvas et al.

49 2007).

50 Connectivity between ocean and estuaries is vital for fish species with complex life cycles, such as

51 migratory species and species dependent on coastal or estuarine habitats as nursery grounds

52 (Harris et al. 2001; Elliott et al. 2007). These species, whose adults inhabit marine environments,

53 have larvae or early juveniles that migrate to coastal or estuarine nursery grounds, where they

54 remain until they grow to subadult stages to later join the marine adult populations (Vasconcelos

55 et al. 2011b). Assuring a good connectivity between the different habitats that a species uses

56 during its life-history is necessary to allow species to access resources (e.g. nursery habitat, food,

57 protection) (Teodósio et al. 2016), promoting the resilience of that population and, consequently

58 of the entire ecosystem (Gawarkiewicz et al. 2007; Mumby and Hastings 2008). Therefore,

59 management strategies would benefit from considering the continuum between all the habitats

60 used by the species, and that requires an understanding of the links between those habitats 
61 (Wolanski 2016). In particular, considering fishes' connectivity it is essential to implement novel

62 management strategies as the ecosystem-based fisheries management. According to this strategy,

63 management focuses not only on the target species, but also contemplates the ecosystem (Pikitch

64 et al. 2004), considering ecological and biological features associated with the target species as

65 nursery grounds and temporarily fish habitats.

66 Larval dispersal is of crucial relevance not only to further perceive population dynamics of marine

67 fish populations, but also to help design and implement efficient management strategies to

68 protect fish species and marine ecosystems, nonetheless data on larval and juvenile dispersal of

69 coastal fishes are still scarce (Di Franco et al. 2012). The comprehension of the links between

70 estuarine and coastal environments is still a challenge, and the majority of the studies on larval

71 dispersal are focused on marine invertebrates and coral reef species (e.g. Cowen et al. 2000;

72 Kinlan and Gaines 2003; Shanks et al. 2003; Almany et al. 2007). Thus, the present study aims to

73 investigate the larval fish dispersal along a temperate NE Atlantic estuarine-ocean gradient by

74 combining simultaneous oceanic and estuarine plankton surveys to specifically: (i) characterize the

75 spatial trends of environmental parameters and ichthyoplankton along an estuarine- ocean

76 gradient; and (ii) investigate the influence of environmental drivers on structural and functional

77 features of the ichthyoplankton assemblages. 
79

80

81

82

83

84

85

86

87

88

89

90

91

92

93

94

95

96

97

98

99

\section{Material and Methods}

\subsection{Study area}

The present study investigated the dispersal of fish larvae along an estuarine-ocean gradient off the NW Iberian Peninsula, located at the northern end of the Canary Current Coastal Province. As for other eastern boundary current systems the regional oceanography is largely affected by the seasonal migration of the trade wind belt that drives the seasonal upwelling which is most intense during the summer period (Longhurst 2007). The pelagic ecosystem is therefore considerably controlled by vertical transport of nutrients into the euphotic zone. The occurrence of several estuaries and rias off the western Iberian shoreline further contributes to the region's productivity. The region, laying in between the influence of the sub-polar and sub-tropical central waters (Mason et al. 2006), typically hosts a variety of fish species with small pelagics being very relevant. The estuaries available offer feeding opportunities and protection to offshore advection therefore are used as nursery grounds by many marine species. The present study focused on one of those estuaries, the Lima estuary, a protected area by the Habitats Directive (1992) and the EU Natura 2000 that, in spite of the major anthropogenic modifications at the outer estuary, still encompasses important intertidal saltmarsh areas and natural banks (Ramos et al. 2015) and functions as nursery area for some fish species amongst which are economically valuable resources (Ramos et al. 2010). The Lima estuary, located off the NW coast is an essential fish habitat and jointly with other estuaries in the vicinity (Cabral et al. 2007; Vasconcelos et al. 2011b) functions as nursery ground for many species, some of them with high economic importance (Ramos et al. 2010). 
100 The temperate Lima River is an open estuary, with a semidiurnal and mesotidal regime (3.7 $\mathrm{m}$ ), 101 with an annual average river flow of $59 \mathrm{~m}^{3} \mathrm{~s}^{-1}$ and salt intrusion extends to $12 \mathrm{~km}$ upstream, with 102 an average flushing rate of $0.5 \mathrm{~m} \mathrm{~s}^{-1}$ and a residence time of 9 days (Ramos et al. 2006a). The Lima 103 estuary can be divided into three geomorphological regions: the polyhaline lower estuary, a deep 104 dredged channel, highly urbanized and modified, sheltering a commercial harbor and a shipyard; 105 the middle estuary, a shallow large area with several tidal islands and salt marsh; and the upper 106 estuary, a narrow channel with natural banks and few tidal islands.

\subsection{Fish larvae sampling}

During the spring of 2009 (in April), the combined ocean-estuarine survey was conducted in six

110 sampling sites along the entire salinity gradient of the Lima estuary (from the river mouth up to 10

$111 \mathrm{~km}$ upstream) and in two transects off the adjacent coastal zone extending approximately $20 \mathrm{~km}$

112 offshore to the $100 \mathrm{~m}$ depth isoline (Figure 1). In the Lima estuary, stations depth was on average 6

$113 \mathrm{~m}$, while in the ocean the average station depth was $48 \mathrm{~m}$. A total of fifteen oceanic stations were

114 occupied on the two transects: seven stations north and eight stations south of the river mouth

115 (Figure 1), onboard IPMA's RV, during a pelagic fish acoustics campaign. In order to sample the

116 same water mass, the estuarine survey was performed in the following flood tide after the oceanic

117 survey, i.e. all samples were taken in a total period of 24 hours, between $31^{\text {st }}$ March and $1^{\text {st }}$ April.

118 Spring was chosen as many winter/spring marine spawning species colonize northern Portuguese

119 estuaries during this season (Ramos et al. 2006), including important marine resources as sardine

120 (Ramos et al. 2009) and flounder (Ramos et al. 2010). 
121 Environmental surveying consisted of measurements of water column physical and chemical

122 parameters, namely temperature, salinity and oxygen saturation with a YSI 6820 CTD in the

123 estuarine stations and CTDF (salinity, temperature, depth and fluorescence) casts in the marine

124 stations. Water samples were collected, in the estuary, with a Van Dorn bottle for further

125 analytical determination of chlorophyll a, nutrients (nitrate, nitrite, ammonium, phosphate and

126 silicate), total particulate matter (TPM) and particulate organic matter (POM), total dissolved

127 carbon (TDC) and dissolved organic carbon (DOC). At sea, water samples were collected from two

128 depths, surface and below the river plume. Water samples were transported to the laboratory in

129 refrigerated ice chests and processed immediately.

130 Estuarine larval fish assemblages were collected with subsurface (1-2m depth) tows performed at

131 a constant velocity of ca. $1 \mathrm{~ms}^{-1}$ for $5 \mathrm{~min}$, with a $500 \mu \mathrm{m}$ mesh size plankton net. In the coastal

132 region, samples covering the entire water column, were obtained through oblique towing of a

133 Bongo system with $335 \mu \mathrm{m}$ mesh size nets. All nets were fitted with flowmeters (Hydro-Bios) for

134 filtered water volume estimation. The volume of water filtered was on average $154 \mathrm{~m}^{3}$ in the 135 estuarine stations and $106 \mathrm{~m}^{3}$ in the marine stations. All the plankton samples were immediately 136 fixed in $4 \%$ buffered formalin $(\mathrm{pH}=8)$ and after sorting, fish larvae were preserved in $95 \%$ ethanol.

\section{$138 \quad 2.3$ Laboratorial processing}

139 All the analytical analyses of water parameters were performed in triplicate. The concentration of 140 chlorophyll a was determined spectrophotometrically after extraction with $90 \%$ acetone (Parsons

141 et al. 1984) with cell homogenization, using the SCOR-UNESCO (1966) trichromatic equation.

142 Dissolved orthophosphate, nitrite, ammonium and silicate concentrations were quantified by the 
143 Grasshoff et al. (1983) methods, and nitrate was analyzed by an adaptation of the spongy

144 cadmium reduction technique (Jones 1984), subtracting nitrite from the total. For TPM and POM

145 assessment, samples were previously filtered through precombusted GF/F glass-fibre filters, which

146 were dried at $105 \circ \mathrm{C}$ (TPM) and then incinerated at 500ㄷ (POM), according to APHA (1992). TDC

147 and DOC were determined using a Shimadzu Instruments TOC-VCSN analyzer following Magalhães

148 et al. (2008).

149 Fish larvae were sorted and identified to the highest possible taxonomic classification, to species

150 level whenever possible. For the most abundant taxa, the total and standard length and the

151 ontogenetic development stage were recorded. Abundance was standardized to the number of

152 larvae per $100 \mathrm{~m}^{3}$ of water filtered.

\section{$154 \quad 2.4$ Data analyses}

155 Environmental variables, larval fish assemblages descriptors (abundance, diversity and species

156 richness), as well as abundance patterns of Platichthys flesus and Sardina pilchardus along the

157 Lima estuarine-ocean gradient were mapped using ArcGIS 10.2 (ESRI, Redlands, CA). To

158 characterize the spatial patterns of each environmental variable, continuous layer maps were

159 created using a deterministic method, the inverse distance weighting (IDW) interpolation.

160 The diversity of larval fish assemblages was expressed by the Shannon-Wiener index (Shannon

161 and Weaner 1963) and assemblage equitability was measured by Pielou's evenness index (J')

162 (Pielou 1966). Each fish species were assigned to an ecological guild derived from estuarine use

163 pattern, according to Franco et al. (2008): estuarine residents (ES), marine migrants (MM; spawn 
164 at sea and regularly enter estuaries in large numbers, including marine species using estuaries as

165 nursery grounds), marine stragglers (MS; spawn at sea and enter estuaries accidentally in low

166 numbers), freshwater species (F) and catadromous species (CA).

167 Differences in water and larval fish composition parameters between estuarine and marine

168 habitats were investigated by the non-parametric test Kruskal-Wallis ANOVA analysis, with habitat

169 (estuary/ocean) as fixed factors. The distribution of the larval fish assemblages along the

170 environmental estuary-coastal gradient was investigated by canonical correspondence analysis

171 (CCA) (Ter Braak 1986), using the software CANOCO (version 4.5, Microcomputer Power, Ithaca,

172 NY). Larval abundances were transformed $[\log (x+1)]$ and downweighting of rare species was

173 performed. Only species with frequency of occurrence higher than $1 \%$ were included in the

174 analyses avoiding any undue effect of rare species. The option used for CCA was triplot scaling

175 with focus on interspecies distances. Significance of the canonical model was given by a Monte

176 Carlo test (Ter Braak and Smilaeur 2002). Inter-set correlation coefficients were used to assess the

177 importance of the environmental variables, and when inter-set $\geq|0.4|$ variables were considered

178 to be biologically important (Rakocinski et al. 1996). Environmental variables were added in their

179 standardized form, namely: mean temperature and salinity of the water column; mean chlorophyll

180 a, nitrate, nitrite, ammonium, phosphate, TPM, POM, TDC and DOC of surface and bottom

181 samples; and depth of the water column. 


\section{Results}

184

\subsection{Environmental conditions}

185 The spatial salinity pattern clearly showed the horizontal salinity gradient along the estuary, with 186 salinity decreasing from the euhaline $(>30)$ to the oligohaline range $(<0.05)$ (Figure 2$)$. Along the 187 study area, salinity of the water column ranged between 0.3 (uppermost estuarine station) and 18835.8 (marine station), significantly decreasing from the oceanic stations towards inland stations $189(\mathrm{H}=12.3 \mathrm{p}<0.01)($ Table 1$)$. In contrast, the water temperature did not vary between the ocean and estuary (Table 1$)$, and the minimum $\left(11.1^{\circ} \mathrm{C}\right)$ and maximum $\left(13.2^{\circ} \mathrm{C}\right)$ values were both registered

191 in the Lima estuarine stations (Figure 2). TPM ranged between $4.8 \mathrm{mg} \mathrm{L}^{-1}$ (estuarine station) and $19265.8 \mathrm{mg} \mathrm{L}^{-1}$ (oceanic station) and POM varied between $2.4 \mathrm{mg} \mathrm{L}^{-1}$ (estuary) and $12.6 \mathrm{mg} \mathrm{L}^{-1}$ (ocean). 193 Both TPM and POM reached higher concentrations in coastal northern and southern stations 194 (Figure 2), decreasing offshore and mainly along the estuarine stations. Significantly higher 195 concentrations of TPM $(H=11.4 p<0.01)$ and POM $(H=7.4 p<0.01)$ were observed at marine stations 196 (Table 1). In the Lima estuary, higher TPM and POM concentrations were associated with the salt 197 marsh area (Figure 2). A similar scenario was observed for the dissolved carbon (Table 1), with 198 significantly higher TDC $(H=11.4 p<0.01)$ concentration at oceanic stations, mainly at the most 199 offshore stations (Figure 2). Although the organic fraction of dissolved carbon was also more 200 concentrated at the most offshore stations (Figure 2), DOC reached significantly higher 201 concentration in the Lima estuary $(H=5.1 p<0.05)$ (Table 1$)$. In the Lima estuary chlorophyll a 202 significantly decreased from the estuarine stations towards offshore $(H=12.3 p<0.01)$ (Figure 3). In 203 fact, in the Lima estuary chlorophyll a ranged between $2.3-3.8 \mathrm{mgL}^{-1}$ in comparison with marine 
204 stations that in average registered a chlorophyll a concentration of $0.7 \pm 0.2 \mathrm{mgL}^{-1}$. Nutrients

205 concentration also differed along the estuarine-ocean gradient (Figure 3). In average there were

206 higher nutrients concentrations in the Lima estuary (Table 1$)$, mainly nitrates $(H=11.4 p<0.01)$,

207 nitrites $(H=3.9 p<0.05)$ and silica $(H=11.4 p<0.01)$.

208

209

\subsection{Larval fish assemblages}

210 A total of 1226 fish larvae collected during the study corresponding to 56 taxa identified, from

211 which 16 taxa were collected within the Lima estuary and 54 at the oceanic stations (Table A-

212 supplementary data). A total of 14 taxa were spread along the estuarine-oceanic gradient (Table

213 2). There was a tendency for these common species to reach higher abundances at the ocean,

214 namely Clupeidae ni (ni - not identified) that was significantly more abundant at the ocean than at

215 Lima estuary $(\mathrm{H}=10.7 \mathrm{p}<0.01)$. In contrast, the common goby Pomatoschistus microps and

216 flounder Platichthys flesus were significantly more abundant at the Lima estuary $(H=8.6 p<0.01$;

$217 \quad H=9.7 p<0.01$, respectively).

218 The total larval fish abundance varied along the gradient (Figure 4), increasing from the upper

219 estuary towards offshore. Fish larvae were significantly $(H=7.0 p<0.01)$ more abundant at the

220 ocean (Table 2), where abundance varied from a minimum of 21.7 larvae $100 \mathrm{~m}^{-3}$ at the

221 northernmost coastal station until a maximum of 196.3 larvae $100 \mathrm{~m}^{-3}$ observed at the southern

222 (Figure 4). Such high abundances observed closely to the Lima river mouth (Figure 4), were mainly

223 composed by Clupeiforms (34\%) and Labridae (28\%). In the Lima estuary, the larval fish

224 assemblage ranged between 6.1-58.5 fish larvae $100 \mathrm{~m}^{-3}$, and the highest abundances were

225 observed in salt marsh area (Figure 4) and were dominated by P. microps. 
226 The larval fish assemblages showed a tendency to include more species and became more diverse

227 from the upstream estuarine stations towards offshore (Figure 3). In fact, the Shannon Wienner

228 index as well as the species richness reached significantly higher values at marine stations than in

229 the Lima estuary $(H=10.7 p<0.01 ; H=8.9 p<0.01$, respectively) (Table 2$)$.

230 From the 56 taxa identified, only six taxa were not assigned to an ecological guild, and $48 \%$ of the

231 taxa were classified as MS, $23 \%$ as MM and $18 \%$ as ES. The coastal larval fish assemblages included

232 five ecological guilds, but only three were observed in the Lima estuary, namely MS, MM and ES,

233 whose relative abundance varied between the Lima estuary and the sea (Figure 5). The spatial

234 distribution of each of these functional groups showed that estuarine species (ES) were more

235 abundant within the Lima estuary, mainly in the saltmarsh zone (Figure 6), representing more than

$23675 \%$ of the assemblage. In fact, this group of species were significantly more abundant at the Lima

237 estuary than in the marine stations $(H=9.7 p<0.05)$. In contrast, marine straggler species (MS) that

238 were only observed in the lower section of the Lima estuary (Figure 6) reached significantly higher

239 abundances in marine stations $(H=5.5 p<0.01)$.

240 The spatial distribution of estuarine dependent species (MM) showed that although these species

241 occurred along the gradient without significant differences between marine and estuarine stations

$242(\mathrm{H}=0.55 \mathrm{p}>0.05)$, they tended to concentrate in the middle and upper sections of the Lima estuary

243 (Figure 6). Focusing on the most abundant MM species that occurred along the gradient, the

244 spatial distribution showed that flounder abundance, gradually increased from offshore towards

245 the upper estuary (Figure 7), where flounder reached significantly higher abundances $(H=9.7$

$246 \mathrm{p}<0.01$ ), overreaching 25 larvae $100 \mathrm{~m}^{-3}$. On the other hand, sardines, Sardina pilchardus, were the 
247

248 249

second most abundant MM species, and they were more abundant at the marine stations, and were only present in small numbers in the lower sections of the Lima estuary (Figure 7).

\subsection{Environmental influence}

Canonical correspondence analysis showed that species were distributed along the first two CCA axes. The first CCA axis (eigenvalue $=0.6$ ) and the second CCA axis (eigenvalue $=0.4$ ) exhibited a high species-environment correlation (0.9) and the effect of the environmental variables on explained distribution of the CCA axes was significant $(F=1.5 p<0.01$, Monte Carlo permutation test). According to the inter-set correlation coefficients chlorophyll a, nitrates and DOC were positively related with first CCA axis, while depth, salinity, TPM and TDC were negatively correlated with the first CCA axis (Table 3). Samples clustered according to their origin, with estuarine and oceanic samples being separated along the first CCA axis. Estuarine samples with higher concentrations of chlorophyll a, nitrates and DOC clustered on the positive side of the ordination plot, while oceanic samples characterized by high salinity and TPM and TDC concentrations clustered on the negative side of first CCA axis (Figure 8a). Oceanic samples were separated along the second CCA axis that was negatively correlated with depth of the water column (Table 3). In fact, samples with less than $50 \mathrm{~m}$ depth clustered on the positive part of second CCA axis, while deeper samples located offshore of the $50 \mathrm{~m}$ isobaths were associated with the negative part of the second CCA axis (Figure 8a). The species classification in ecological guilds showed that functional groups were distributed along the first CCA axis, with MS tending to cluster in the negative part of first CCA axis, associated with high salinity. In contrast, ES showed a wider 
268 distribution along the estuarine-ocean gradient (Figure 8b) and were associated with lower 269 salinities and high Chlorophyll a and nitrates concentrations. MM species occurred in between 270 these two functional groups along the estuarine gradient.

272 4. Discussion

\section{$273 \quad 4.1$ Larval fish dispersal according to species functional traits}

274 The present study showed for the first time the dispersal of larval fish assemblages along the Lima 275 estuarine-ocean gradient. The coordinated plankton collection in the ocean and estuary allowed to 276 verify a mixture of estuarine and marine species occurring along a gradient of $30 \mathrm{~km}$ from the $277100 \mathrm{~m}$ isobaths offshore until the upper section of the Lima estuary. The species collected in this 278 study are frequently observed in planktonic studies of the region, and the abundances registered 279 were within the range of previous studies for the same time of the year (e.g. Azeiteiro et al. 2006; 280 Ramos et al. 2006a; Garrido et al. 2009). These evidences support the representativeness of the 281 data collected during this study and constitutes valuable baseline information to help 282 understanding the connectivity between the ocean and the Lima estuary.

283 A major finding of the present study was to show that species distribution along the Lima 284 estuarine-ocean gradient were in accordance with their ecological traits relative to species use of 285 estuarine environments. Overall, each ecological guild group exhibited the expected spatial 286 distribution along the gradient: estuarine species (ES) were more abundant in the Lima estuary, 287 mainly in the salt marsh zone, while marine stragglers (MS) were associated with the ocean and 288 restricted to the lower section of the Lima estuary, and finally marine migrants (MM) were spread 
289 along the gradient, with higher abundances in the middle and upper sections of the Lima estuary.

290 The ecological guild classification is based on all life-cycle of the species (Elliott et al. 2007), and

291 this study emphasized the importance of early larval stages for the determination of the species

292 traits. One example was the European flounder $P$. flesus, whose larvae presented a typical spatial

293 gradient of a marine migrant species, since its abundance gradually increased from offshore

294 (spawning areas) towards the upper estuary where abundance peaked. This species, a typical user

295 of coastal/estuarine nursery areas (Elliott et al. 2007), reproduces in winter/early spring in marine

296 waters (e.g. Campos et al. 1994; Dando et al. 2011; Koubbi et al. 2006) and migrates during the

297 early life stages to nursery grounds (e.g. Jager 2001; Martinho et al. 2008). The spatial pattern of

298 flounder larvae observed in this study (i.e. abundance increasing from offshore towards the

299 estuary) was in accordance with the previous studies that proposed the Lima estuary as a nursery

300 area (Ramos et al. 2010; Amorim et al. 2016). According to those studies, P. flesus recruitment to

301 estuary occurs early during the larval phase, with larvae migrating from the offshore spawning

302 grounds to the estuarine nursery area. The present results further reinforce the evidence of

303 connectivity between the ocean and the Lima estuary for a marine migrant species as $P$. flesus.

304 On the other hand, sardine S. pilchardus larvae were more abundant at the sea and were only

305 present in small numbers in the lower sections of the estuary. Such spatial distribution is typical of

306 marine stragglers, although S. pilchardus was classified as marine migrant species, in accordance

307 with the classification proposed by Franco et al. (2008) and also corroborating previous studies in

308 the Lima estuary during which high abundances of S. pilchardus larvae were observed in the inner

309 sections of the estuary (Ramos et al. 2009). European sardine larvae tend to dominate the 
310 ichthyoplankton community in the Western Iberian upwelling ecosystem, particularly during

311 colder months of the year (Garrido et al. 2009) and are thought to be limited to coastal areas (e.g.

312 John et al. 1996; Chícharo et al. 1998; Olivar et al. 2003; Santos et al, 2004), and that is in

313 agreement with the results from this work, since higher S. pilchardus abundance were observed at

314 the oceanic stations. However, the observed abundances within the estuarine stations (0.5-3.2

315 sardine larvae $100 \mathrm{~m}^{-3}$ ) were lower than those found in prior studies in the Lima estuary, where $S$.

316 pilchardus larval abundance reached 60.8 larvae $100 \mathrm{~m}^{-3}$ (Ramos et al. 2006a; 2009). The

317 comparatively lower abundances of the sardine larvae observed during this work (also quite

318 restricted in time) might reflect the inter-annual variability of estuarine recruitment, derived from

319 variability in the sardine densities (Massé et al. 2016) and inter-annual variation of oceanographic

320 and estuarine hydrological conditions (Ramos et al. 2009; Amorim et al. 2016). This study gives

321 support to the need of further research in understanding the sardine early life history and

322 ascertaining the importance of estuarine habitats for this pelagic species.

\subsection{Environmental drivers of larval dispersal}

325 The spatial distribution of the environmental variables showed that the study area covered two

326 distinct water masses, and some variables varied greatly along the estuarine-ocean gradient,

327 namely S, Chla, TPM, POM, TDC, DOC, $\mathrm{NO}_{3}, \mathrm{NO}_{2}$ and Si. The Lima estuary was characterized by

328 lower salinity and higher concentrations of chlorophyll $a$, nitrates, nitrites and silica, typical

329 features for the time of the year (April) (Ramos et al. 2006b; Amorim et al. 2016). At the oceanic

330 stations, temperature and salinity values (Massé et al. 2016) and chlorophyll $a$ and nutrients 
331 concentrations (Moita 2001; Cabrita et al. 2015) were within the ranges commonly observed in

332 the region during spring. Coastal salinity was considerably higher, as expected and presented

333 higher concentrations of particulate matter, including the organic fraction and total carbon. The

334 present study showed that the adjacent northern coastal stations presented higher values of

335 particulate matter (TPM and POM), what is an unusual pattern, since estuaries are typically more

336 turbid than coasts. However, the Lima estuary is characterized by clear waters with reduced

337 turbidity levels (Ramos et al. 2006b; Ramos et al. 2009). Also, the observed higher TPM and POM

338 concentrations in the northern adjacent coast may be associated with the presence of several

339 small estuaries located northerly of the Lima river mouth, whose run-off is advected southwards

340 due to the prevailing northern-southern currents (Amorim et al. 2016). The water characteristics

341 varied less at the ocean in comparison with estuarine stations. Estuaries are interface ecosystems

342 functioning as boundaries between rivers and the ocean, where abrupt changes in salinity,

343 temperature, oxygen and turbidity occur due to the influence of tides and the mixing of marine

344 and fresh waters (e.g. Elliott and Wollanski 2015). In this study, the extreme and steep gradients

345 observed in many physical and chemical variables were derived from the mixing of the oceanic

346 water mass with the freshwater inflow, since the sampling survey was conducted during the flood

347 tide. Not many species can cope with the physiological stress induced by the environmental

348 variability of estuarine habitats (Elliott and Hemingway 1995; Elliott et al. 2007), and as result,

349 estuaries are characterized by comprising less species than the adjacent coastal areas. In fact, our

350 results illustrated this feature, since the species richness and assemblage diversity were lower in

351 the estuary in comparison with the oceanic stations. 
352 Larval fish dispersal contemplates passive and active transport mechanisms (e.g. Harris et al. 2001;

353 Schulderman et al. 2012), controlled by hydrodynamic conditions and by water characteristics as

354 temperature, salinity, turbidity (e.g. Grouthes and Cowen 1999; Harris et al. 2001; Santos et al.

355 2004; Ramos et al. 2006b; Amorim et al. 2016). According to the canonical correspondence

356 analysis results, salinity, chlorophyll a, nitrates, and depth were the most relevant environmental

357 variables correlated with the larval fish assemblages of the Lima estuarine-oceanic gradient. In

358 fact, these water parameters have been usually associated with the occurrence of abundance

359 fluctuations of larval stages of fishes. Salinity and depth (which also reflect location) have been

360 widely identified as important environmental drivers of larval fish assemblages (Harris et al. 2001;

361 Ramos et al. 2006b and references therein), controlling the species composition of

362 ichthyoplankton assemblages in function of the species tolerance to salinity gradients. Chlorophyll

$363 a$ has also been identified as an important environmental control of larval fish assemblages, since

364 spring peaks of chlorophyll $a$ derived from phytoplankton blooms have been associated with

365 estuarine peaks of larval fish abundance (e.g. Livingston et al. 1997; Garcia et al. 2003; Amorim et

366 al. 2016). In fact, some authors consider this synchronization as a strategy following the 'match-

367 mismatch' hypothesis (Cushing 1990), according to which the temporal and spatial overlap

368 between peaks in food resources (e.g., phytoplankton and subsequently zooplankton) and larval

369 abundance regulates survival of larval fishes and subsequent recruitment (Cushing 1990; Chick and

370 Van Den Avyle 1999).

371 The first canonical axis, which represented the spatial Lima estuarine-ocean gradient, separated

372 typical marine species associated with high salinity from estuarine resident species as $P$. microps 
373 and $P$. minutus and estuarine-dependent species as $P$. flesus. Interestingly, species were more or

374 less separated along the spatial gradient accordingly to their ecological functional classification.

375 Results showed that MS species were positively correlated with salinity and were associated with

376 marine stations. On the other hand, ES species showed a wider distribution and were associated

377 with lower salinities and high chlorophyll a concentrations of the inner Lima estuarine stations. ES

378 were more abundant in the Lima estuary, mainly in the salt marsh zone, where species like $P$.

379 microps and P. minutus tend to concentrate (Ramos et al. 2006a; and data not published). Marine

380 migrant species were distributed along the estuarine-ocean gradient, with some species positively

381 correlated with salinity as sea bass Dicentrarchus labrax. Others as $P$. flesus were negatively

382 correlated with salinity and associated with high concentrations of chlorophyll a. Actually,

383 chlorophyll $a$ has been identified as a major environmental driver of the occurrence of $P$. flesus

384 larvae in the Lima estuary (Amorim et al. 2016). The second canonical axis was negatively

385 correlated with depth, and represented a second environmental gradient separating shallow

386 coastal stations from deep offshore stations. Species were also separated along this coastal-

387 offshore gradient, and species like Centrolabrus exoletus, Labrus merula, and Lipophrys trigloides

388 were negatively correlated with depth, since they are typical coastal species associated with

389 shallow habitats (Whitehead et al. 1984). In contrast, larval stages of demersal species as Ciliata

390 mustela or bathypelagic species as Micromessistius poutassou were positively correlated with

391 depth and clustered associated with the deepest stations. Hence, the results of this study clearly

392 showed the importance of the water characteristics in controlling the spatial patterns and

393 dispersal of the larval fish species along an estuarine-oceanic gradient. 


\subsection{Importance of larval fish dispersal and connectivity to management}

Processes occurring during the pelagic larval phase of fish life are well acknowledged to influence the spatial distribution of fish populations (e.g. McGilliard and Hilborn 2008; Schludermann et al. 2012), and ultimately the strength of annual recruitment (Cowen and Sponaugle 2009; Vasconcelos et al. 2011b) and abundance of adult populations (Able and Fahay 2010). Connectivity between marine and estuarine environments is fundamental for several fish species

401 (Cowen and Sponaugle 2009), in some particular phase of their life cycle (Elliott et al. 2007; Franco et al. 2008). Larval dispersal is then essential to marine species to reach suitable coastal/estuarine nursery areas, where early development stages of marine fishes can growth faster and thus increasing their probability of survivorship before joining the adult populations. The results of this study showed that larval stages of species commercially exploited, as sardine and flounder, were dispersed along the Lima estuary-ocean corridor, indicative of the connectivity between the habitats. Particularly for these species is mandatory that human activities do not compromise the connectivity between ocean and estuarine habitats, what could pose additional pressures to the stocks. Thus, larval dispersal and connectivity with nursery areas should not be forgotten in management plans and the scientific research needs to continue increasing our understanding of

411 the population's movements which then will help in the conservation and preservation of the

412 marine ecosystems. Knowing that larval fish dispersal is fundamental to the efficiency of

413 governance practices as MPA (McGilliard and Hilborn 2008; Di Franco et al. 2012), the present

414 study contributed to give empirical evidences of estuarine-ocean connectivity and, in the future it 
415 will be interesting to integrate estuarine stations in the current stock monitoring plans for some

416 fisheries. Given that the Atlanto-Iberian sardine stock has reached historically minimum values of

417 population abundance and recruitment strength (ICES 2015; Massé et al. 2016), the relevance of

418 studies as the present one is important to foster comprehensive understanding of estuarine-ocean

419 connectivity (and should be replicated in other larger estuaries), what has been acknowledged as

420 having important applications for management and conservation of ecosystems (Cowen and

421 Sponaugle, 2009).

\section{$423 \quad 5 . \quad$ Acknowledgments}

424 The authors would like to thank all those involved in the field surveys and sampling sorting and

425 laboratory procedures from both IPMA and the Hydrobiology Laboratory at ICBAS-University of

426 Porto. Particular acknowledgements are due to Professor A.A. Bordalo from the Hydrobiology

427 Laboratory. The authors would also like to thank E. Amorim for her help guidance to produce the

428 GIS maps. SR was funded by FCT through a Post-doctoral fellowship (SFRH/ BPD/102721/2014).

429 This research was partially supported by the Strategic Funding UID/Multi/04423/2013 through

430 national funds provided by FCT -Foundation for Science and Technology and European Regional

431 Development Fund (ERDF), in the framework of the programme PT2020. Surveying at sea was

432 undertaken during an IPMA PELAGO acoustics campaign funded via the National Biological

433 Sampling Programme (PNAB/EU DCF - Data Collection Framework). 


\section{References}

436 Able, K.W., Fahay, M.P. 2010. Ecology of Estuarine Fishes: Temperate Waters of the Western 437 North Atlantic. Johns Hopkins University Press.

438 Almany, G.R., Berumen, M.L., Thorrold, S.R., Planes, S., Jones, G.P., 2007. Local replenishment of 439 coral reef fish populations in a marine reserve. Science 316: $742-744$.

440 Amorim, E., Ramos, S., Elliott, M. and Bordalo, A. A. 2016. Immigration and early life stages recruitment of the European flounder (Platichthys flesus) to an estuarine nursery: The influence of environmental factors. J. Sea Res. 107:56-66.

APHA 1992. Standard methods for the examination of the water and wastewater. Washington, DC: American Public Health Association.

Azeiteiro, U.M., Bacelar-Nicolau, L., Resende, P., Gonçalves, F. and Pereira, M.J. 2006. Larval fish distribution in shallow coastal waters off North Western Iberia (NE Atlantic). Estuar. Coast. Shelf. S. 447 69(3):554-566.

448 Bignami, S., Enochs, I. C., Manzello, D. P., Sponaugle, S. and Cowen, R. K. 2013. Ocean acidification 449 alters the otoliths of a pantropical fish species with implications for sensory function. PNAS 450 110(18): 7366-7370.

451 Cabral, H., Vasconcelos, R., Vinagre, C., Franca, S., Fonseca, V., Maia, A., Reis-Santos, P., Lopes, M., 452 Ruano, M., Campos, J., Freitas, V., Santos, P. and Costa, M. 2007. Relative importance of estuarine 453 flatfish nurseries along the Portuguese coast. J. Sea Res. 57(2-3):209-217.

454 Cabrita, M.T., Silva, A., Oliveira, P. B., Angélico, M.M. and Nogueira, M. 2015. Assessing 455 eutrophication in the Portuguese continental exclusive economic zone within the European 456 marine strategy framework directive. Ecol. Ind. 58:286-299.

457 Campos, W.L., Kloppmann, M. and von Westernhagen, H. 1994. Inferences from the horizontal 458 distribution of dab Limanda limanda (L.) and flounder Platichthys flesus (L.) larvae in the 459 southeastern North Sea. Neth. J. Sea Res. 32:277-286.

460 Chick, J.H. and Van Den Avyle, M.J. 1999. Zooplankton variability and larval striped bass foraging: 461 Evaluating potential match/mismatch regulation. Ecol.App. 9(1):320-334.

462 Chícharo, M., Chícharo, L., Valdes, I., lopez-Jamar, E. and Ré, P. 1998. Estimation of starvation and 463 diet variation of the RNA/DNA ratios in field-caught Sardina pilchardus larvae of the north of 464 Spain. Mar. Ecol. Prog. Ser. 164: 273-283. 
465

466

467

468

469

470

471

472

473

474

475

476

477

478

479

480

481

482

483

484

485

486

487

488

489

490

491

492
Clobert, J., Le Galliard, J.F., Cote, J., Meylan, S., Massot, M. 2009 Informed dispersal, heterogeneity in animal dispersal syndromes and the dynamics of spatially structured populations. Ecol. Lett. 12: 197-209.

Cote, J., Clobert, J., Brodin, T., Fogarty, S., Sih, A. (2010). Personality-dependent dispersal: characterization, ontogeny and consequences for spatially structured populations. Philos. T. Roy. Soc. B 365: 4065-4076.

Cowen, R. K., Lwiza, K. M., Sponaugle, S., Paris, C. B. and Olson, D. B. 2000. Connectivity of marine populations: open or closed? Science, 287(5454): 857-859.

Cowen, R.K. and Sponaugle, S. 2009. Larval dispersal and marine population connectivity. Annu. Rev. Marine. Sci. 2009(1):443-466.

Cushing, D.H. 1990. Plankton production and year-class strength in fish populations: an update of the match/mismatch hypothesis. Adv. Mar. Biol. 26:249-293.

Dando, P.R. 2011. Site fidelity, homing and spawning migrations of flounder Platichthys flesus in the Tamar estuary, South West England. Mar. Ecol. Prog. Ser. 430:183-196.

Di Franco, A., Gillanders, B.M., De Benedetto, G., Pennetta, A., De Leo, G.A. and Guidetti, P. 2012. Dispersal patterns of coastal fish: implications for designing networks of marine protected areas. PLoS One 7(2):e31681.

Elliott, M., Whitfield, A.K., Potter, I.C., Blaber, S.J.M., Cyrus, D.P., Nordlie, F.G. and Harrison, T.D. 2007. The guild approach to categorizing estuarine fish assemblages: a global review. Fish and Fish. 8(3):241-268.

Elliott, M. and Dewailly, F. 1995. The structure and components of European fish assemblages. Neth. J. Sea Res. 29(3-4):397-417.

ESRI, 2013. ArcGIS Resources Center. http://resources.arcgis.com/en/home/(accessed October 2013).

Franco, A., Elliott, M., Franzoi, P., Torricelli, P. 2008. Life strategies of fishes in European estuaries: the functional guild approach. Mar. Ecol. Prog. Ser. 354:219-228.

França, S., Costa, M.J. and Cabral, H.N. 2009. Assessing habitat specific fish assemblages in estuaries along the Portuguese coast. Estuar. Coast. Shelf. S. 83(1):1-12. 
493

494

495

496

497

498

499

500

501

502

503

504

505

506

507

508

509

510

511

512

513

514

515

516

517

518

519

520

521

522

Garcia, A.M., Vieira, J.P. and Winemiller, K.O. 2003. Effects of 1997-1998 El Nino on the dynamics of the shallow-water fish assemblage of the Patos Lagoon Estuary (Brazil). Estuar. Coast. Shelf. S. 57:489-500.

Garrido, S., Ben-Hamadou, R., Santos, A. M. P., Ferreira, S., Teodósio, M. A., Cotano, U., Irigoien, X., Peck, M.A., Saiz, E. and Ré, P. 2015. Born small, die young: Intrinsic, size-selective mortality in marine larval fish. Scientific Reports 5:17065.

Garrido, S., Santos, A.M.P., dos Santos, A. And Ré, P. 2009. Spatial distribution and vertical migrations of fish larvae communities off Northwestern Iberia sampled with LHPR and Bongo nets.

Estuar. Coast. Shelf. S. 84(4): 463-475.

Gawarkiewicz, G., Monismith, S., Largier, J. 2007. Observing larval transport processes affecting population connectivity: progress and challenges. Oceanography 20:40-53.

Grasshoff, K., Ehrhardt, M., Kremling, K. 1983. Methods of seawater analysis. Second revised and extended edition (p. 419). Weinheim: Verlag Chemie.

Grothues, T.M. and Cowen, R.K. 1999. Larval fish assemblages and water mass history in a major faunal transition zone. Cont. Shelf. Res. 19:1171-1198.

Harris, S.A., Cyrus, D.P. and Beckley, L.E. 2001. Horizontal trends in larval fish diversity and abundance along an ocean-estuarine gradient on the northern KwaZulu-Natal coast, South Africa. Estuar. Coast. Shelf. S. 53(2):221-235.

Houde, E.D. 2008. Emerging from Hjort's shadow. J. Northwest Atl. Fish. Sci. 41: 53-70.

ICES. 2013. Management plan evaluation for sardine in Divisions VIIIc and IXa. In Report of the ICES Advisory Committee, 2013. ICES Advice, 2013. Book 7, Section 7.3.5.1

ICES. 2015. Report of the Working Group on Southern Horse Mackerel, Anchovy and Sardine (WGHANSA), 24-29 June 2015, Lisbon, Portugal. ICES CM 2015/ACOM:16. 612 pp.

Jager, Z. 2001. Transport and retention of flounder larvae (Platichthys flesus L.) in the Dollard nursery (Ems estuary). J. Sea Res. 45:153-171.

Johnson, D.W., Grorud-Colvert, K., Sponaugle, S. and Semmens, B. X. 2014. Phenotypic variation and selective mortality as major drivers of recruitment variability in fishes. Ecol. Letters 17: 743755.

John, H.C., Ré, P. and Zuelicke, C.1996. Sardine larvae in a spring-upwelling event off northern Portugal. Cienc. Biol. Ecol. Syst. 16: 193-198. 
523 Jones, M.N. 1984. Nitrate reduction by shaking with cadmium: Alternative to cadmium columns.

524 Water Res. 18:643-646.

525 Kinlan, B.P. and Gaines, S.D. 2003. Propagule dispersal in marine and terrestrial environments: a

526 community perspective. Ecology, 84(8): 2007-2020.

527 Koubbi, P., Loots, C., Cotonnec, G., Harlay, X., Grioche, A., Vaz, S., Walkey, M., Carpentier, A.2006.

528 Spatial patterns and GIS habitat modelling of Solea solea, Pleuronectes flesus and Limanda limanda

529 fish larvae in the eastern English Channel during the spring. Sci.Mar. 70(2):147-157.

530 Lasker, R. 1975. Field criteria for survival of anchovy larvae: the relation between inshore

531 chlorophyll maximum layers and successful first feeding. U.S. Fish. Bul.73:453-462.

532 Livingston, R.J., Niu, X., Lewis, F.G. and Woodsum, G.C. 1997. Freshwater input to a gulf estuary:

533 long-term control of trophic organization. Ecol. App. 7:277-299.

534 Longhurst, A. L. 2007. Ecological geography of the sea, $2^{\text {nd }}$ ed., Academic Press, London, 542 pp.

535 Magalhães, C., Teixeira, C., Teixeira, R., Machado, A., Azevedo, I., Bordalo, A.A. 2008. Dissolved

536 organic carbon and nitrogen dynamics in the Douro River estuary, Portugal. Cienc. Mar. 34:271-

537282.

538 Martinho, F., Leitão, R., Neto, J.M., Cabral, H., Lagardère, F. and Pardal, M.A.,2008. Estuarine 539 colonization, population structure and nursery functioning for 0-group sea bass (Dicentrarchus

540 labrax), flounder (Platichthys flesus) and sole (Solea solea) in a mesotidal temperate estuary. J.

541 Appl. Ichthyol. 24: 229-237.

542 Mason, E., Coombs, S., Oliveira, P. B. 2006. An overview of the literature concerning the 543 oceanography of the eastern North Atlantic region. Relat. Cient. Téc. Inst. Invest. Pescas Mar 33, $54458 \mathrm{pp}$.

545 Massé, J., Uriarte, A., Angélico, M. M., and Carrera, P. Pelagic survey series for sardine and 546 anchovy in ICES subareas 8 and 9 (WGACEGG) - Towards an ecosystem approach. ICES 547 Cooperative Research Report 332. (in press)

548 McGilliard, C.R. and Hilborn, R. 2008. Modeling no-take marine reserves in regulated fisheries:

549 assessing the role of larval dispersal. Can. J. Fish. Aquat. Sci. 65(11):2509-2523.

550 Miller, B. and Kendall, A. W. 2009. Early life history of marine fishes. University of California Press. 
551 Mumby, P.J., Hastings, A. 2008. The impact of ecosystem connectivity on coral reef resilience. J.

552 Appl Ecol. 45: 854-862

553 Olivar, M., Catalan, I., Emelianov, M. and de Puelles, M. 2003. Early stages of Sardina pilchardus 554 and environmental anomalies in the Northwestern Mediterranean Estuar. Coast. Shelf. S. 56(3-

555 4):609-619.

556 Parsons, T.R., Maita, Y., Lalli, C.M. 1984. A manual of chemical and biological methods for 557 seawater analysis (pp. 101-112). Elmsford: Pergamon.

558

559

560

561

562

563

564

565

566

567

568

569

570

571

572

573

574

575

576

577

578

579

Pielou, E.C.1966. The measurement of diversity in different types of biological collections. J. Theor. Biol. 13:131-144.

Pikitch, E., Santora, C., Babcock, E.A., Bakun, A., Bonfil, R., Conover, D O P., Doukakis, P., Fluharty, D., Heneman, B., Houde, E.D., Link, J., Livingston, P. A., Mangel, M., McAllister, M.K., Pope, J., Sainsbury, K.J., 2004. Ecosystem-based fishery management. Science 305: 346-347.

Potter, I.C., Beckley, L., Whitfield, A. and Lenanton, R. 1990. Comparisons between the role played by estuaries in the life-cycle of fishes in temperate Western Australia and South Africa. Environ. Biol. Fish. 28(1-4):143-178.

Potter, I.C., Tweedley, J.R., Elliott, M. and Whitfield, A.K. 2015. The ways in which fish use estuaries: a refinement and expansion of the guild approach. Fish and Fish. 16:230-239.

Rakocinski, C. F., Lyczkowski-Shultz, J. and Richardson, S. L. 1996. Ichthyoplankton assemblage structure in Mississippi sound as revealed by canonical correspondence analysis. Estuar. Coast. Shelf. S. 43:237-257.

Ramos, S., Cowen, R.K., Ré, P. and Bordalo, A.A. 2006a. Temporal and spatial distributions of larval fish assemblages in the Lima estuary (Portugal). Estuar. Coast. Shelf. S. 66(1):303-314.

Ramos, S., Cowen, R.K., Paris, C., Ré, P. and Bordalo, A. A. 2006b. Environmental forcing and larval fish assemblage dynamics in the Lima River estuary (northwest Portugal). J. Plankt. Res. 28(3):275286.

Ramos, S., Ré, P. and Bordalo, A.A. 2009. New insights into the early life ecology of Sardina pilchardus (Walbaum, 1792) in the northern Iberian Atlantic. Sci. Mar.73(3):449-459.

Ramos, S., Ré, P. and Bordalo, A.A.2010. Recruitment of flatfish species to an estuarine nursery habitat (Lima estuary, NW Iberian Peninsula). J. Sea Res. 64 (4):473-486. 
Ramos, S., Cabral, H. and Elliott, M. 2015. Do fish larvae have advantages over adults and other components for assessing estuarine ecological quality? Ecol. Indic. 55:74-85.

Relvas, P., Barton, E.D., Dubert, J., Oliveira, P.B., Peliz, A., Silva, J.C.B. and Santos, M.P. 2007. Physical oceanography of the western Iberia ecosystem: Latest views and challenges. Progr. Oceanography 74: 149-173.

Sale, P., Van Lavieren, H., Lagman, M.A., Atema, J., Butler, M., Fauvelot, C., Hogan, J., Jones, G., Lindeman, K., Paris, C., 2010. Preserving reef connectivity: a handbook for marine protected area managers. Connectivity Working Group. Coral Reef Targeted Research \& Capacity Building for Management Program. UNU-INWEH.

Santos, A., Peliz, A., Dubert, J., Oliveira, P., Angelico, M. and Ré, P. 2004. Impact of a winter upwelling event on the distribution and transport of sardine (Sardina pilchardus) eggs and larvae off western Iberia: a retention mechanism. Cont. Shelf. Res. 24(2):149-165.

Santos, A.M.P., M.A. Chícharo, A. Dos Santos, T. Moita, P.B. Oliveira, Á. Peliz and Ré, P. 2007. Physical-biological interactions in the life history of small pelagic fish in the Western Iberia upwelling Ecosystem. Progr. Oceanog. 74(2-3):192-209.

Shanks, A.L., Grantham, B.A., Carr, M.H. 2003.Propagule dispersal distance and the size and spacing of marine reserves. Ecol. Appl. 13:159-169.

Shannon, C.E., Weaver, W. 1963. The mathematical theory of communications. University of Illinois Press, Urbana, IL.

Shaw, R. F., Rogers, B. D., Cowen, J. H. Jr. and Herke, W. H. 1988. Ocean-estuary coupling of ichthyoplankton and nekton in the Northern Gulf of Mexico. Am. Fish. S. S. 3: 77-89.

Schludermann, E., Tritthart, M., Humphries, P., and Keckeis, H. 2012. Dispersal and retention of larval fish in a potential nursery habitat of a large temperate river: an experimental study. Can. J. Fish. Aquat. Sci. 69(8): 1302-1315.

Teodósio, M.A., Paris, C.B., Wolanski, E., and Morais, P. 2016. Biophysical processes leading to the ingress of temperate fish larvae into estuarine nursery areas: A review. Estuar. Coast. Shelf. S. 183:187-202.

Ter Braak, C.J.F. 1986. Canonical correspondence analysis: A new eigenvector technique for multivariate direct gradient analysis. Ecology 67:1167-1179. 
609 Ter Braak, C.J.F. and Smilaeur, P. 2002. CANOCO Reference manual and CanoDraw for Windows 610 user's guide: software for Canonical Community Ordination (version 4.5). Microcomputer Power, 611 Ithaca, NY, USA.

612 Vasconcelos R.P., Reis-Santos P., Cabral H.N., Costa J.L. and Costa M.J. 2011a. River-Coast

613 Connectivity, Estuarine Nursery Function and Coastal Fisheries.In: Wolanski E and McLusky DS

614 (eds.) Treatise on Estuarine and Coastal Science, Vol. 10, pp. 81 - 107. Waltham: Academic Press.

615 Vasconcelos, R.P., Reis-Santos, P., Costa, M.J., Cabral, H.N. 2011b. Connectivity between estuaries 616 and marine environment: integrating metrics to assess estuarine nursery function. Ecol. Indic.

$617 \quad 11: 1123-1133$.

618 Whitehead, P. J., Bauchot, M. L., Hüreau, J. C., Nielsen, J. and Tortonese, E. 1984. Fishes of the 619 North-Easter Atlantic and the Mediterranean. UNESCO, Paris.

620 Wolanski, E. 2016. Bounded and unbounded boundaries-Untangling mechanisms for estuarine621 marine ecological connectivity: Scales of $m$ to $10,000 \mathrm{~km}-\mathrm{A}$ review. Estuar. Coast. Shelf. S. In press.

622 Wolanski, E. and Elliott, M. 2015. Estuarine Ecohydrology: an Introduction. Elsevier 


\section{Figures Captations}

Figure 1. Location of the sampling stations of the northern $(\odot)$ and southern $(\bullet)$ transects, and estuarine $(\star)$ stations along the Lima estuary-ocean gradient.

Figure 2. Spatial variation of a) salinity (psu); b) temperature ( $\mathrm{C}$ ) ; c) total particulate matter (TPM: $\mathrm{mg} \mathrm{L}^{-1}$ ); d) particulate organic matter (POM: $\mathrm{mg} \mathrm{L}^{-1}$ ); e) total dissolved carbon (TDC: $\mathrm{mg} \mathrm{L}^{-1}$ ); and f) dissolved organic carbon (DOC: $\mathrm{mg} \mathrm{L}^{-1}$ ) along the Lima estuarine-ocean gradient in April 2009.

Figure 3. Spatial variation of a) chlorophyll a $\left(\mathrm{mg} \mathrm{m}^{-3}\right)$; and nutrients $\left(\mu \mathrm{M} \mathrm{L}^{-1}\right)(\mathrm{b}) \mathrm{NH}_{4}$ - ammonium; c) $\mathrm{NO}_{3}$ - nitrates; d) $\mathrm{NO}_{2}$-nitrites; e) $\mathrm{PO}_{4}$ - phosphates; f) Si- silica) concentrations along the Lima estuarine-ocean gradient in April 2009.

Figure 4. Spatial variation of a) larval fish abundances (no. larvae $100 \mathrm{~m}^{-3}$ ), b) diversity $\left(\mathrm{H}^{\prime}\right)$ and c) species richness (no. species) along the Lima estuarine-ocean gradient in April 2009.

Figure 5. Relative abundance (\%) of each ecological guilds of the Lima estuary (estuary) and marine larval fish assemblages, considering all species collected. ES- estuarine residents; MM-marine migrants; MS marine stragglers; other (species without an ecological guild assigned).

Figure 6. Spatial variation of the relative abundance (in \%) of each functional groups of the larval fish assemblages along the Lima estuarine-ocean gradient in April 2009. ES- estuarine residents; MS marine stragglers; and MM-marine migrants.

Figure 7. Spatial variation of flounder (Platichthys flesus) and sardine (Sardina pilchardus) larval fish abundance (no. larvae $100 \mathrm{~m}^{-3}$ ) along the Lima estuarine-ocean gradient in April 2009.

Figure 8. Ordination diagrams for the first two canonical correspondence axes of the canonical correspondence analysis: a) triplot between larval fish species, environmental variables and sampling stations (blue-ocean; green-estuarine); and b) biplot between environmental variables and larval fish species classified accordingly to their ecological guild classification in terms of estuarine use (green-estuarine species (ES); blue-marine stragglers (MS); and yellow- marine migrant species (MM). S- sanility; T- temperature; Depth-depth of the water column; TPM- total particulate matter; POM- particulates organic matter; TDC- total dissolved carbon; DOC- dissolved organic carbon (DOC); $\mathrm{NH}_{4}$ - ammonium; $\mathrm{NO}_{3}$ - nitrates; $\mathrm{NO}_{2}$-nitrites; $\mathrm{PO}_{4}$ - phosphates; Chlachlorophyll a concentration. For species codes please see Table 2 and Table A-supplementary data. 


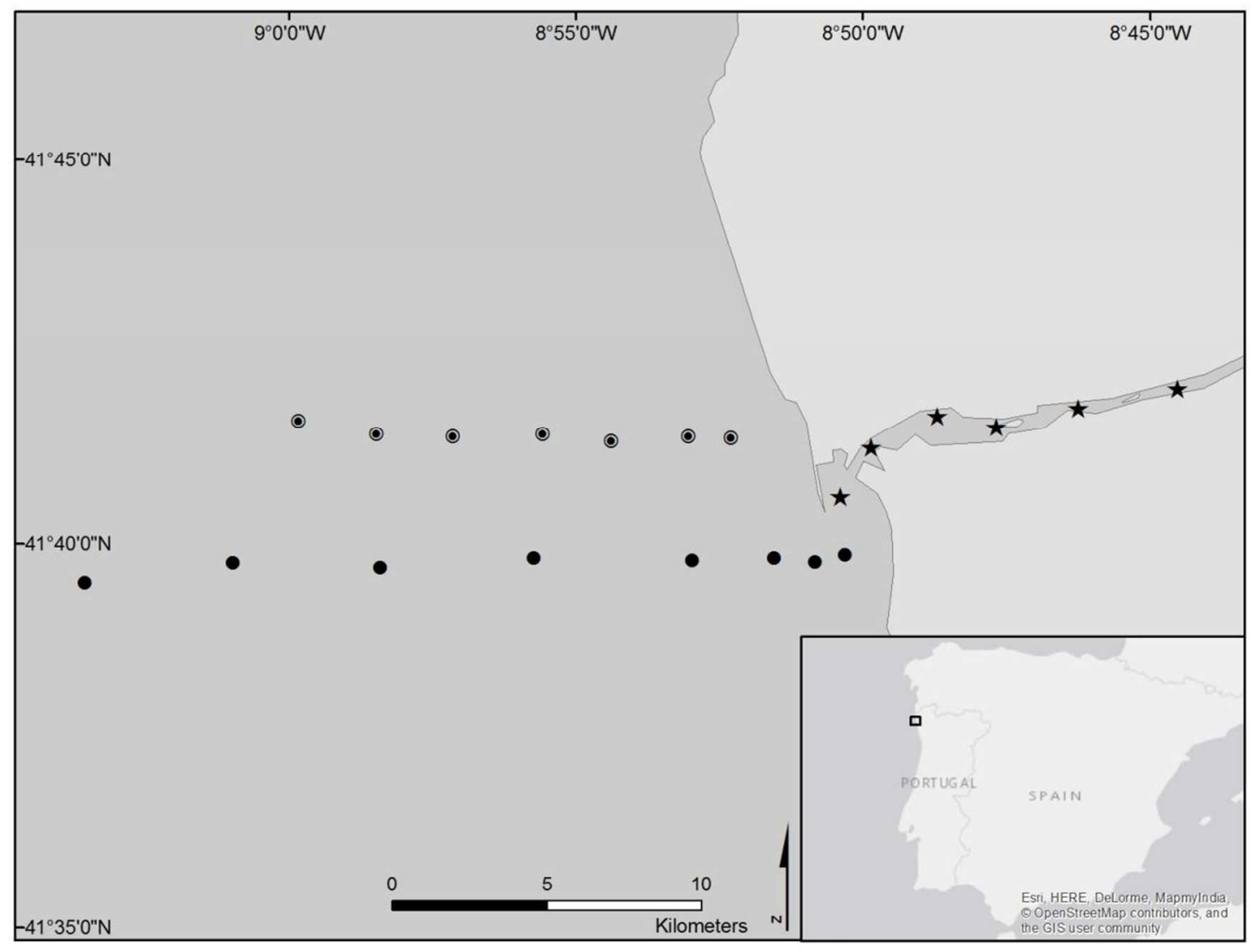

Figure 1. 


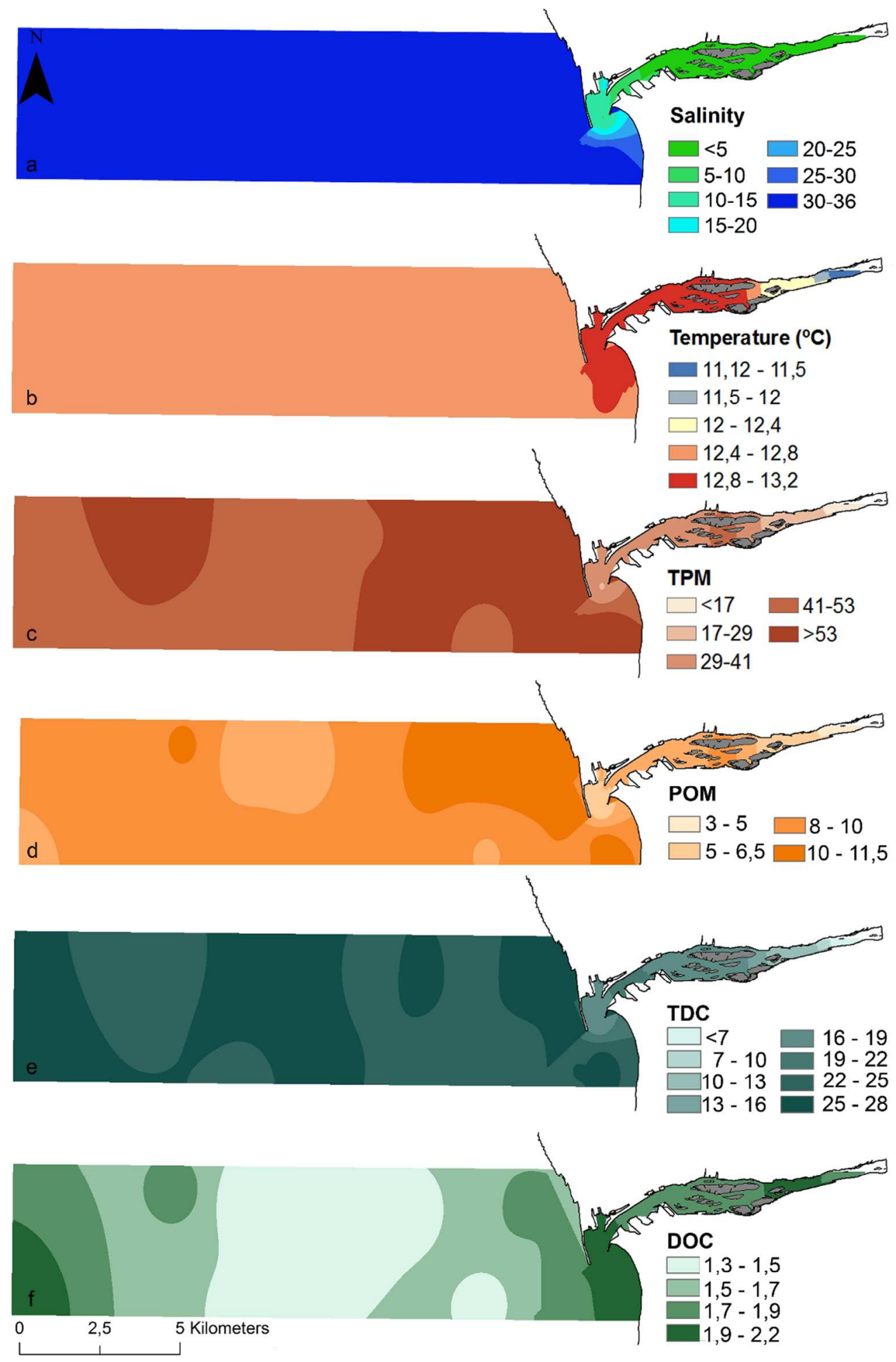

Figure 2. 


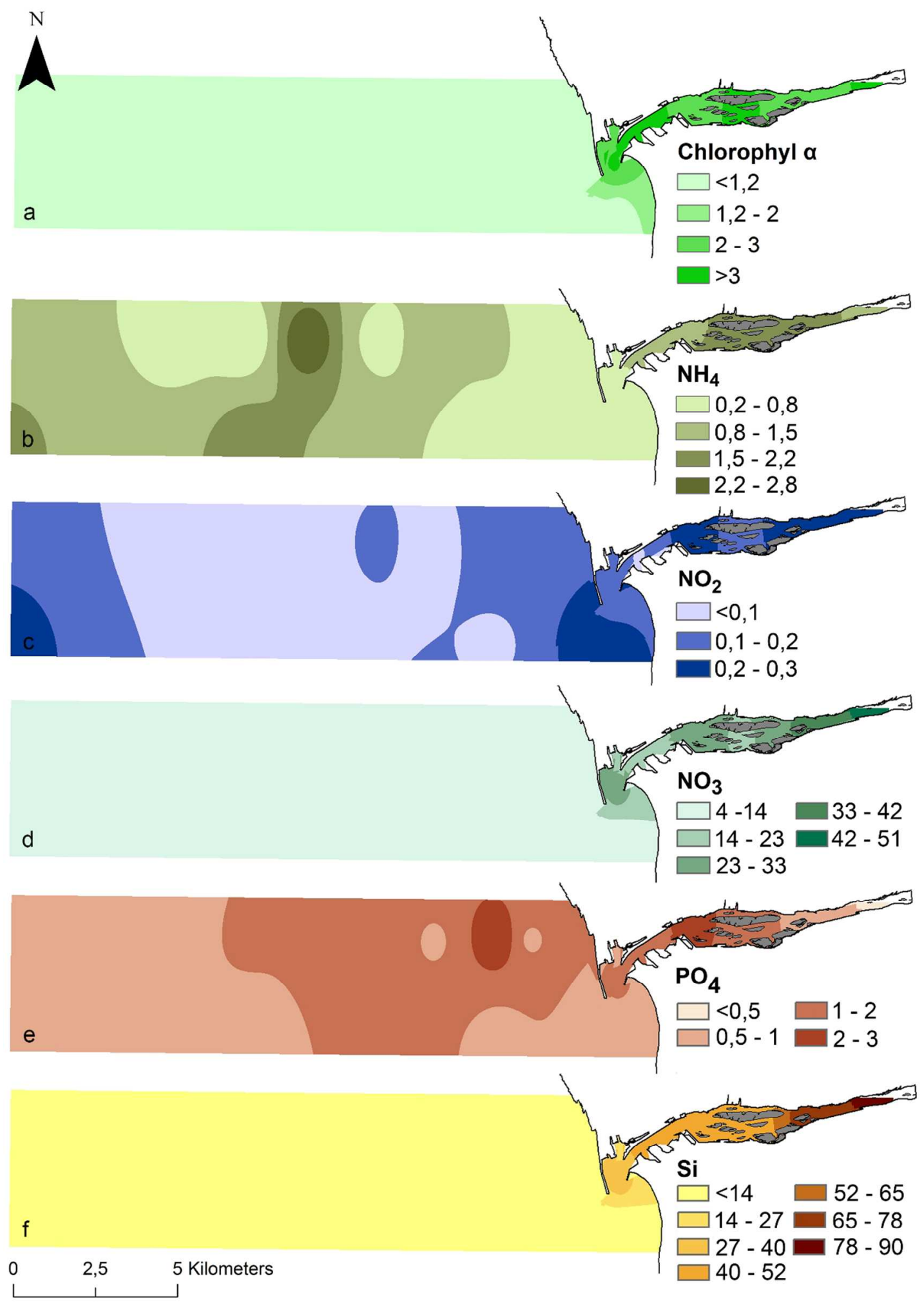

Figure 3. 

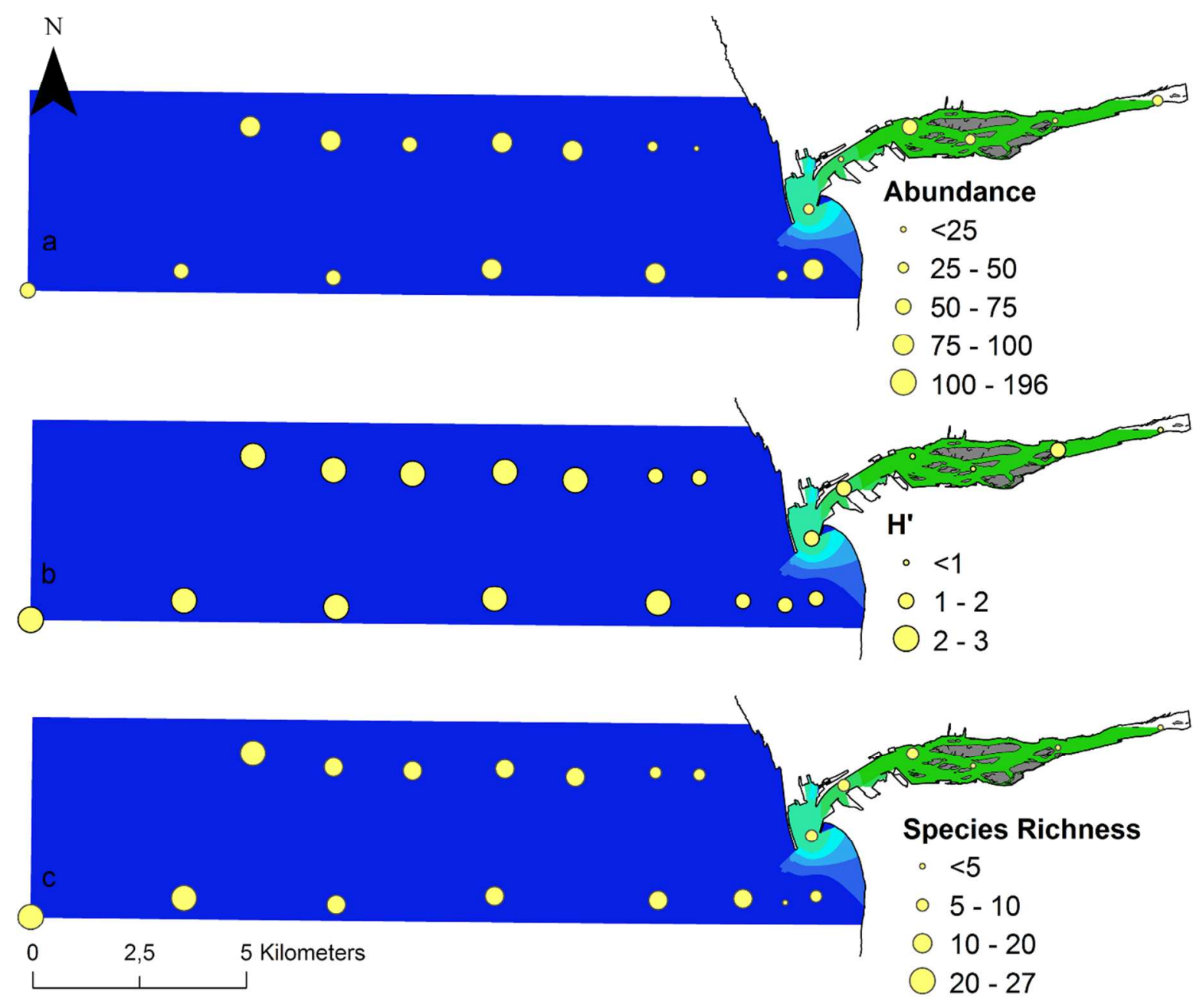

Figure 4. 


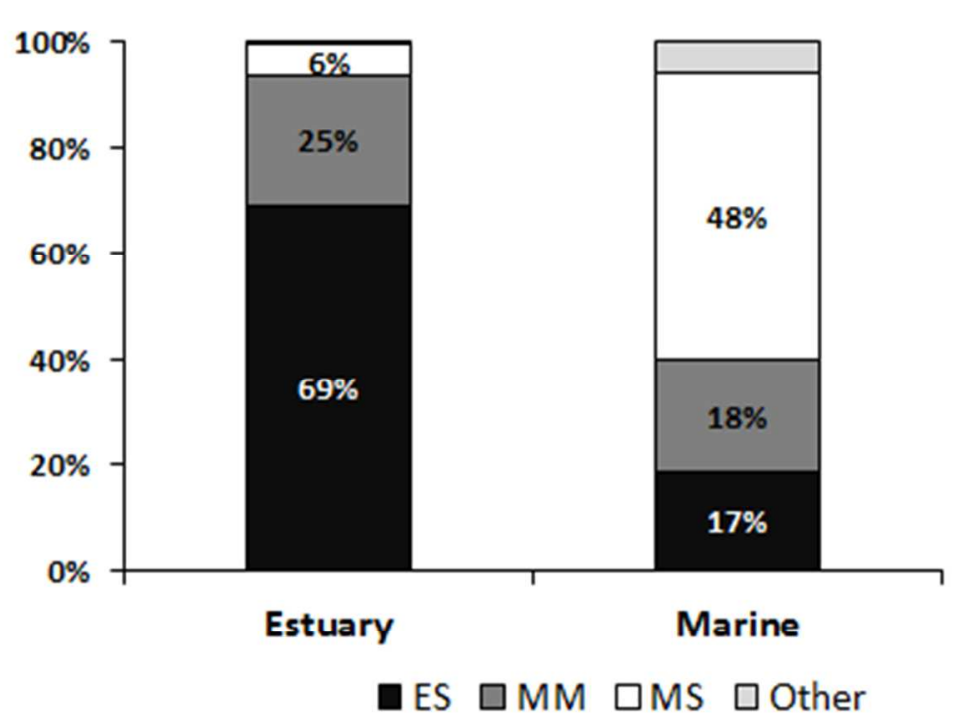

Figure 5. 


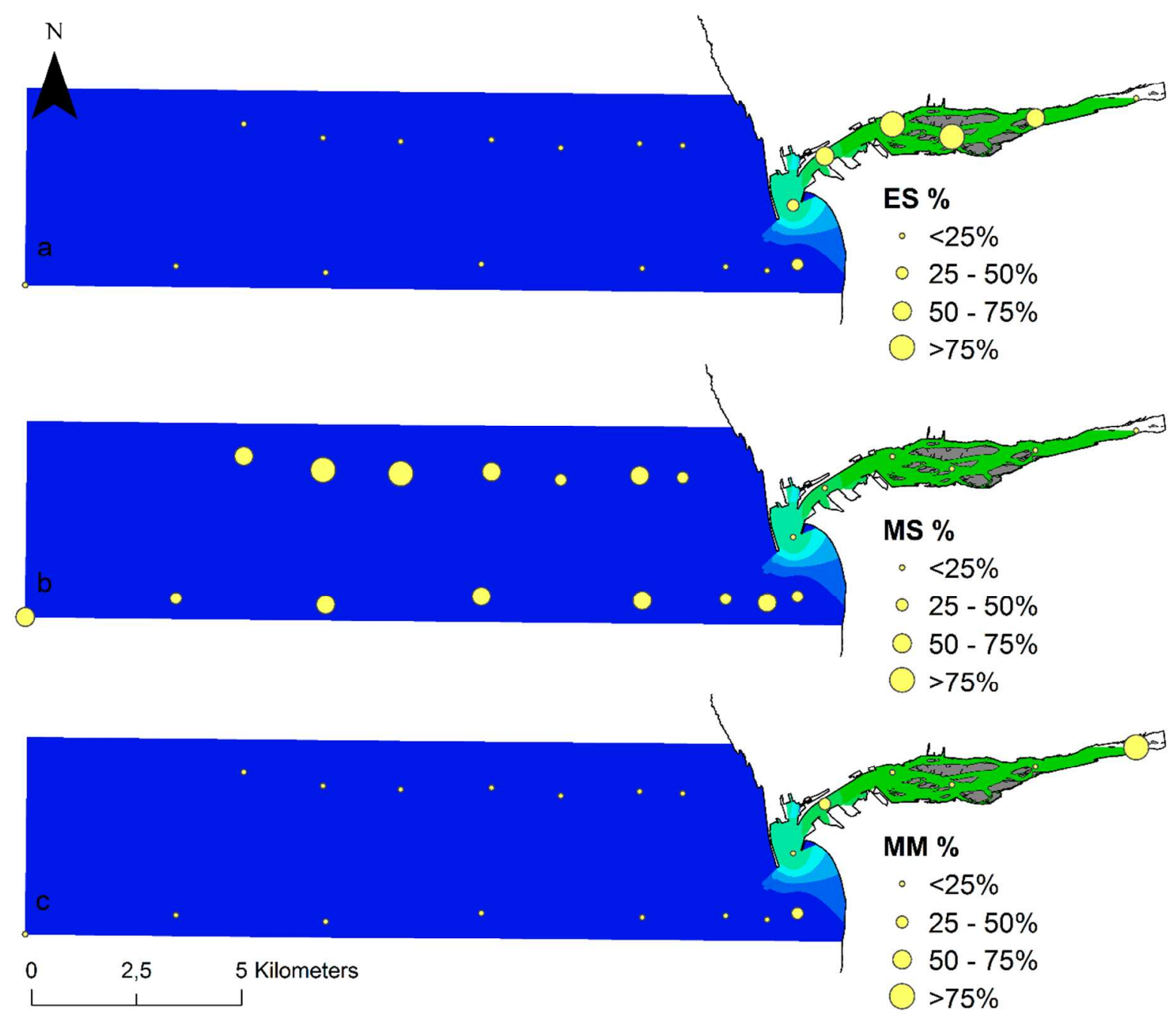

Figure 6. 


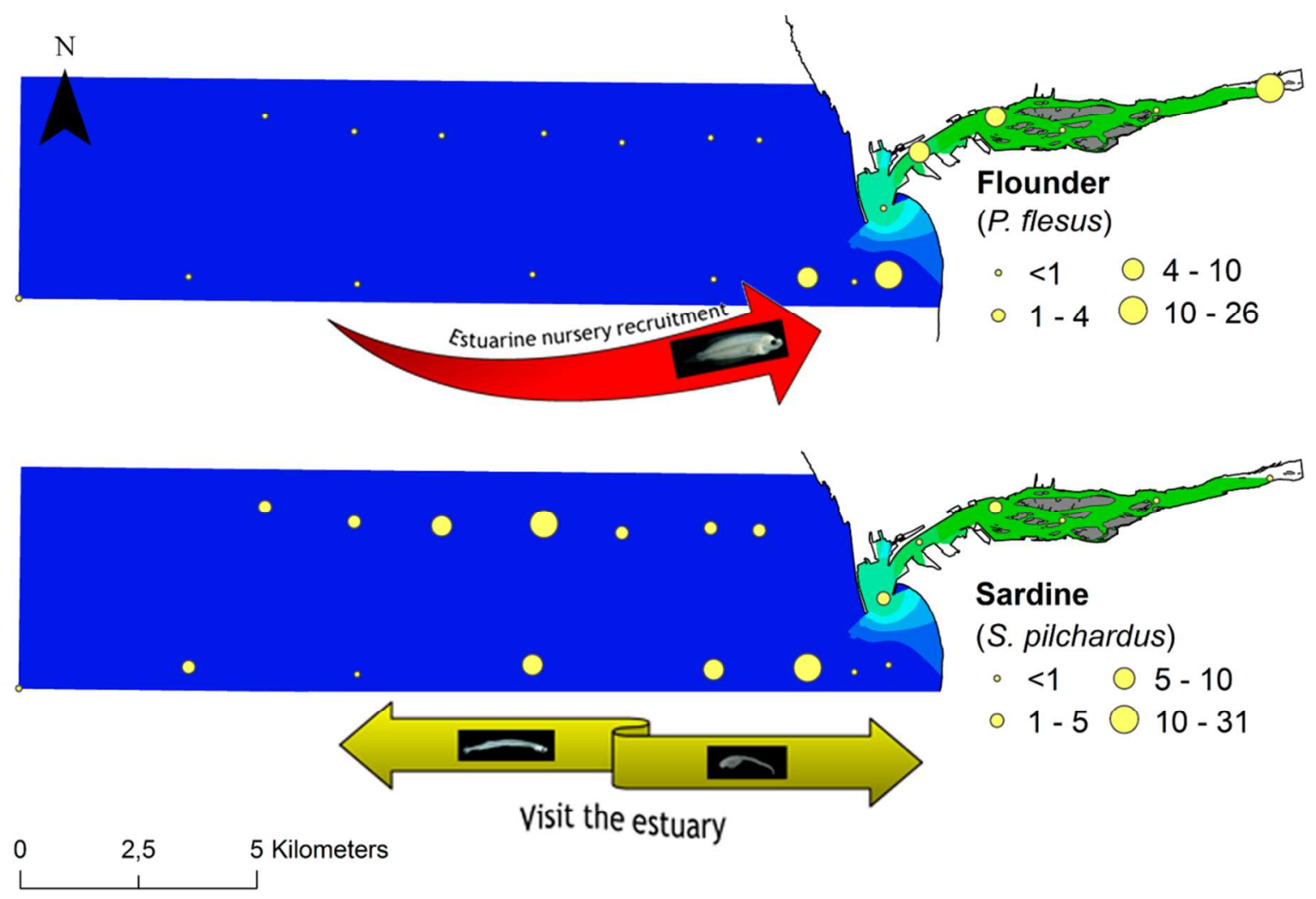

Figure 7. 

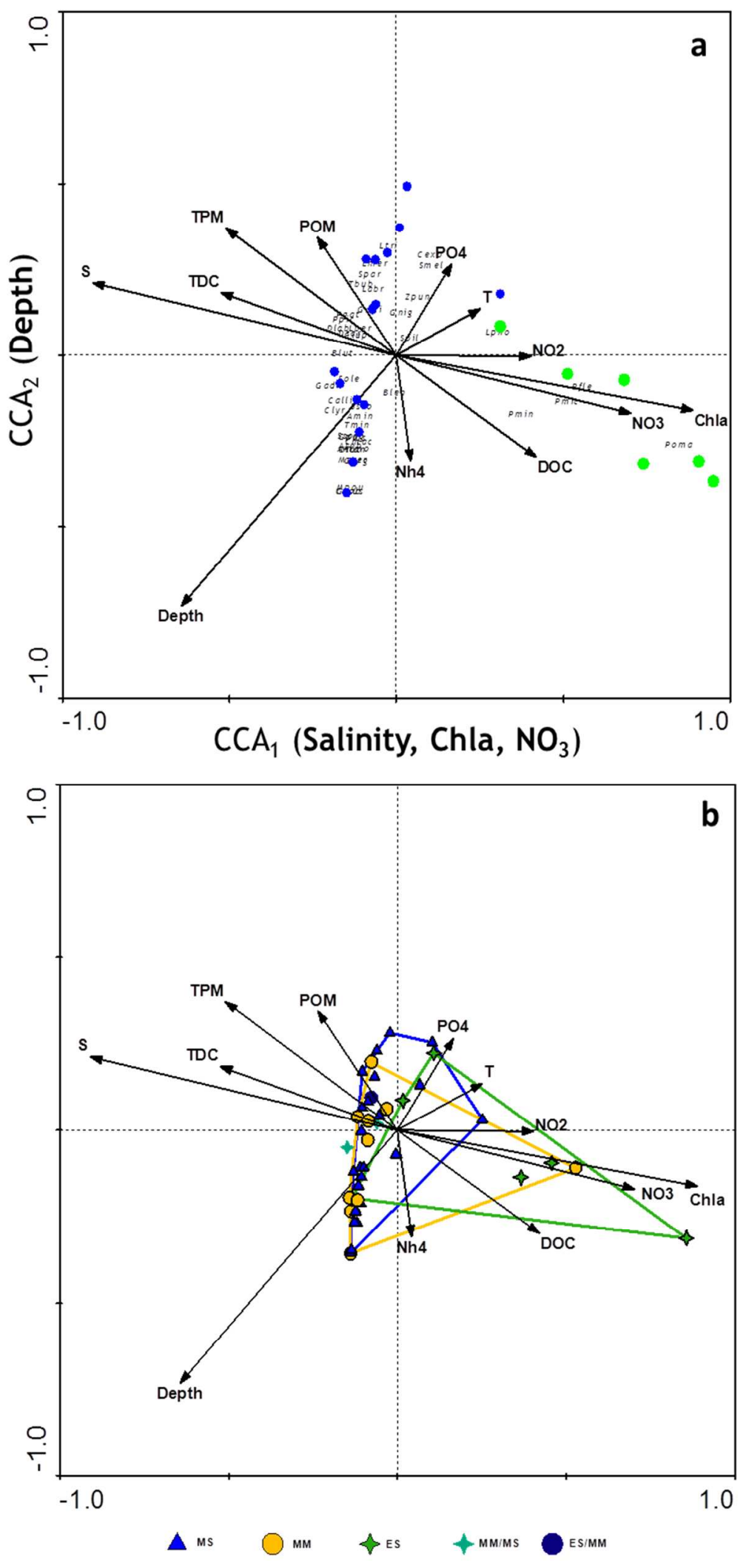

Figure 8. 


\section{Tables}

Table 1. Water parameters of the Lima estuary and adjacent coastal zone along the water column.

\begin{tabular}{|c|c|c|c|c|}
\hline & \multicolumn{2}{|c|}{ Lima estuary } & \multicolumn{2}{|c|}{ Ocean } \\
\hline & Average & SD & Average & SD \\
\hline Temperature (으) & 12.60 & 0.69 & 12.56 & 0.09 \\
\hline Salinity (psu) & 13.00 & 15.73 & 35.69 & 0.09 \\
\hline Chlorophyll a (mg m ${ }^{-3}$ ) & 3.20 & 1.50 & 0.65 & 0.16 \\
\hline TPM $\left(\mathrm{mg} \mathrm{L}^{-1}\right)$ & 28.88 & 23.06 & 54.22 & 5.90 \\
\hline $\operatorname{POM}\left(\mathrm{mg} \mathrm{L}^{-1}\right)$ & 6.07 & 3.33 & 9.18 & 1.52 \\
\hline $\operatorname{TDC}\left(\mathrm{mg} \mathrm{L}^{-1}\right)$ & 15.01 & 8.80 & 25.25 & 1.93 \\
\hline $\mathrm{DOC}\left(\mathrm{mg} \mathrm{L}^{-1}\right)$ & 1.95 & 0.19 & 1.67 & 0.28 \\
\hline $\mathrm{Nh}_{4}\left(\mu \mathrm{ML}^{-1}\right)$ & 1.28 & 0.60 & 0.94 & 0.83 \\
\hline $\mathrm{NO}_{3}\left(\mu \mathrm{M} \mathrm{L}^{-1}\right)$ & 29.79 & 18.68 & 6.56 & 1.28 \\
\hline $\mathrm{NO}_{2}\left(\mu \mathrm{M} \mathrm{L}^{-1}\right)$ & 0.20 & 0.06 & 0.15 & 0.06 \\
\hline $\mathrm{PO}_{4}\left(\mu \mathrm{M} \mathrm{L}^{-1}\right)$ & 1.24 & 0.94 & 1.05 & 0.71 \\
\hline $\mathrm{Si}\left(\mu \mathrm{ML}^{-1}\right)$ & 54.62 & 38.16 & 3.69 & 1.75 \\
\hline
\end{tabular}


Table 2. Abundance (no. larvae $100 \mathrm{~m}^{-3}$ ), Shannon Wienner index $\left(\mathrm{H}^{\prime}\right)$ and species richness (no. of species) of the larval fish assemblages of Lima estuary and coastal area, and the ecological guild classification and abundance of the fourteen fish larvae species common along the estuarine-ocean gradient.

\begin{tabular}{|c|c|c|c|c|c|c|}
\hline \multirow[t]{2}{*}{ Species } & \multirow{2}{*}{$\begin{array}{l}\text { CCA } \\
\text { code }\end{array}$} & \multirow[t]{2}{*}{ EG } & \multicolumn{2}{|c|}{ Lima estuary } & \multicolumn{2}{|c|}{ Ocean } \\
\hline & & & Average & SD & Average & SD \\
\hline Centrolabrus exoletus & Cexo & MS & 0.33 & 0.81 & 3.46 & 7.29 \\
\hline Cupeidae ni & Clup & MS & 0.08 & 0.20 & 7.89 & 8.68 \\
\hline Gobius niger & Gnig & ES & 0.43 & 1.06 & 0.70 & 2.08 \\
\hline Labridae ni & $L a b r$ & MS & 0.16 & 0.25 & 2.25 & 2.73 \\
\hline Labrus bergylta & Lber & MS & 0.27 & 0.66 & 1.74 & 2.50 \\
\hline Lipophrys pholis & Lpho & MS & 0.28 & 0.69 & 0.65 & 1.60 \\
\hline Platichthys flesus & Pfle & MM & 5.84 & 9.96 & 1.58 & 5.29 \\
\hline Pomatoschistus microps & Pmic & ES & 15.39 & 18.25 & 0.41 & 0.89 \\
\hline Pomatoschistus minutus & Pmin & ES & 1.03 & 1.70 & 0.12 & 0.34 \\
\hline Pomatoschistus pictus & Ppic & MS & 0.08 & 0.19 & 1.51 & 2.74 \\
\hline Sardina pilchardus & Spil & MM & 0.95 & 1.36 & 5.33 & 7.91 \\
\hline Sparidae ni & Spar & MM & 0.08 & 0.20 & 1.17 & 2.69 \\
\hline Symphodus melops & Smel & ES & 1.49 & 2.42 & 5.59 & 9.47 \\
\hline Zeugopterus punctatus & Zpun & MS & 0.43 & 1.06 & 0.46 & 1.35 \\
\hline Total abundance & & & 30.45 & 23.46 & 73.23 & 39.49 \\
\hline Diversity ( $\left.\mathbf{H}^{\prime}\right)$ & & & 0.97 & 0.95 & 2.25 & 0.44 \\
\hline Species richness & & & 5.17 & 4.89 & 14.47 & 6.32 \\
\hline
\end{tabular}


Table 3. Inter-set correlations of environmental variables with the first two CCA axes, based on the log-transformed abundance of larval fish assemblages of the estuarine-coastal gradient.

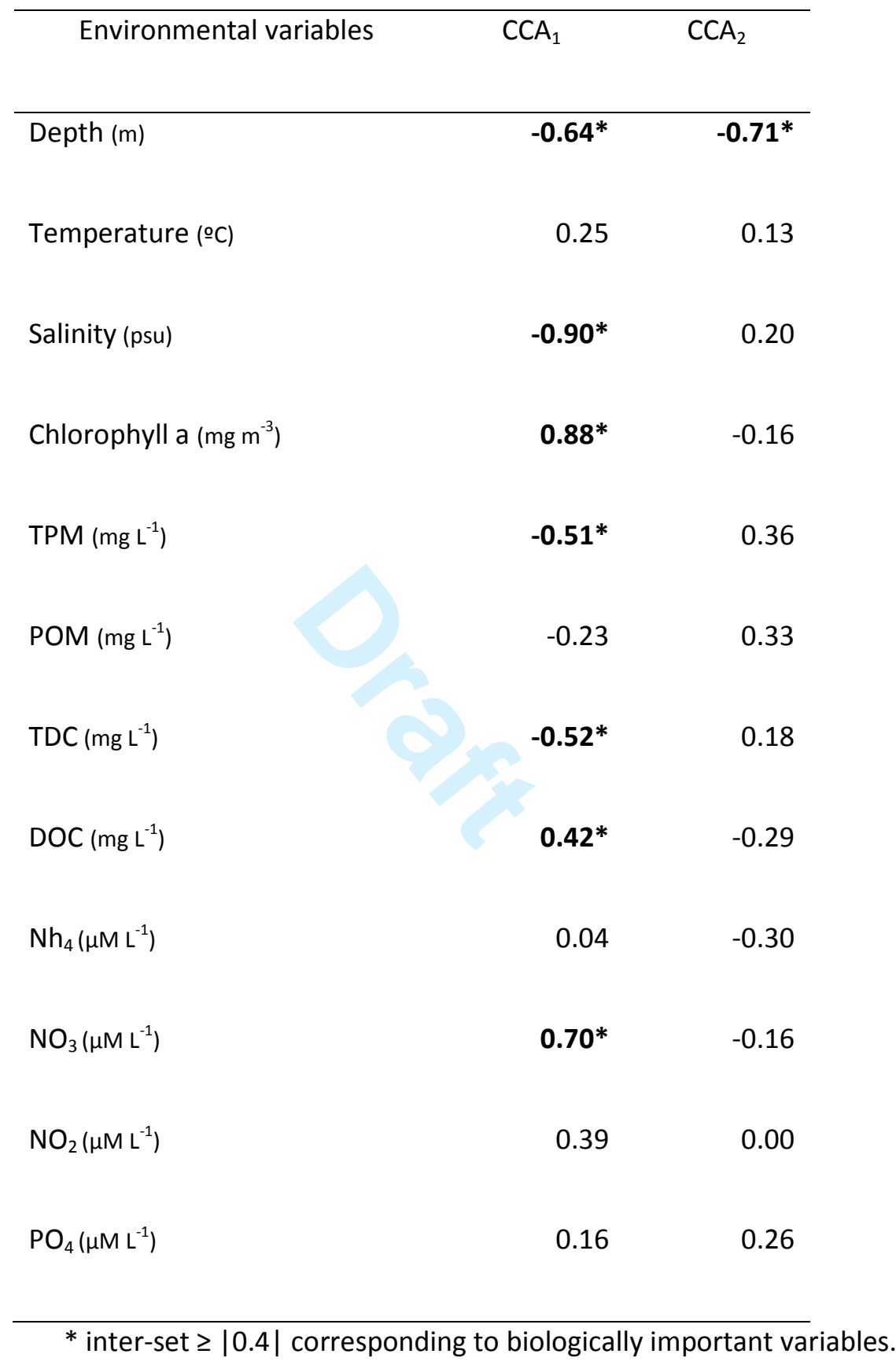

